\title{
Survey on Benefits and Barriers of E-Procurement: Malaysian SMEs Perspective
}

\author{
Khu Say Eei ${ }^{1}$, Wahidah Husain ${ }^{2}$, Norlia Mustaffa ${ }^{3}$ \\ School of Computer Sciences, Universiti Sains Malaysia, 11800 Minden, Penang, Malaysia \\ E-mail. ${ }^{1}$ say.ee@hotmail..com, $\left\{^{2}\right.$ wahidah, ${ }^{3}$ norlia\}@cs.usm.my
}

\begin{abstract}
Procurement is one of the major aspects for an enterprise to improve its supply chain management and hence enterprise performance. The advent of Internet has introduced e-commerce and drastically changing the way procurement is done to improve operation efficiency and reduce transaction cost significantly. Thereby, this lead to the term "e-procurement" or "e-purchasing". However, many Small and Medium Enterprises (SMEs) still perceive e-procurement as infeasible although e-procurement is introduced in the early 2000 . Hence, this paper attempts to provide a comprehensive survey on existing literature with regards to the benefits and barriers of e-procurement in the perspective of Malaysian SMEs. Highlighting the benefits and identifying the major barriers of SMEs e-procurement implementation enables formation of effective solution to encourage more adoption of eprocurement system in Malaysian SMEs.
\end{abstract}

Keywords- E-Business; E-Commerce; E-Procurement; SMEs

\section{INTRODUCTION}

The integration of business and Internet has long been a common phenomenon around the world. Nevertheless, procurement as one of the major functions of a firm which could substantially affect the firm's profitability or even survival has migrated into electronic platform many large economic entities. The implementation of e-procurement in total will increase the efficiency and productivity of a firm's business operations. However, majority of the Small and Medium Enterprises (SMEs) are still sceptical of the potential benefits mainly due to limited human and financial resources. In addition, developing countries such as Malaysia lacks comprehensive technology development and standards to implement the system. The communities too are lacking the initiative in changing practices to embrace eprocurement. Hence, tremendous efforts and cooperation are required among government, system developers and vendors, SME owners and employees to breakthrough these barriers.

The rest of the paper will be organized as follows: Section II of this paper provides basic background in the use of ICT in business. Section III defines the SMEs in Malaysia context and the need to improve SMEs productivity. Section IV examines how e-procurement benefits economic entities in general. Section V specifies the tangible and intangible benefits brought by $\mathrm{e}-$ procurement to SMEs, and section VI describes the external and internal barriers of SMEs to implement e-procurement system. Section VII provides some approaches to overcome the barriers faced by SMEs, and section VIII concludes the paper and present the limitations of this study and possible direction of future research.

\section{Connecting Business to ICT}

Internet is one of the information and communication technologies well-known for its ability to transmit and receive information with almost no geographical restriction at a very fast rate. Internet has forever changed the way business was conducted and managed ever since the Internet blooms in the early 1990s. Before that, Internet was expensive to deploy and complicated to use, and is usually exclusively used as an electronic data interchange (EDI) among large, well-funded organization only. However, with the price drop in acquisition of personal computers as well as the creation of World Wide Web not long after, following closely behind by user-friendly browser featuring graphical user interfaces, the Internet has becoming more and more common in most households. It has become so popular that the number of websites has jumped from around 50 in 1992 to around 27 million by 2002 [1]. As more users are connected via the Internet, some businesses start to conduct business over the Internet to tap into this potentially huge market. In U.S. alone, 124 million Internet users have transacted a total of $\$ 27.6$ billion sales over the Internet in 
2000 , and this has risen to $\$ 143.3$ billion Internet sales generated by 227 million Internet users in 2009 [2, 3].

The Internet market can be loosely classified according to their target customers: Business-to-Business (B2B) are businesses seeking to trade with other businesses, Businessto-Consumer (B2C) are businesses selling their product or service to consumers, while in Business-to-Government (B2G) businesses are selling their product or service to government agencies. The applications employed by these businesses to enable transactions or procurements with other entities over the Internet are generally termed electronic procurement, or e-procurement. In other words, eprocurement is the use of integrated information technology for part of or all the procurement functions, from the beginning to end, i.e. from searching, sourcing, negotiating, ordering, and receipt to post-purchase review (as shown in Fig. 1) $[4,5]$. E-procurement has been recently receiving much attention from businesses, industries and governments as it is reportedly become a powerful tool to improve effectiveness and efficiencies as well as service quality of its adopters.

\section{NATURE OF SMALl AND MEDIUM ENTERPRISES IN MALAYSIA}

As mentioned before, the Internet was only accessible to large organizations with ample resources, but it is now mostly available to almost anyone. In the light of this development, the use of the Internet in the Small-toMedium Enterprises (SMEs) is inevitable and crucial for their survival.

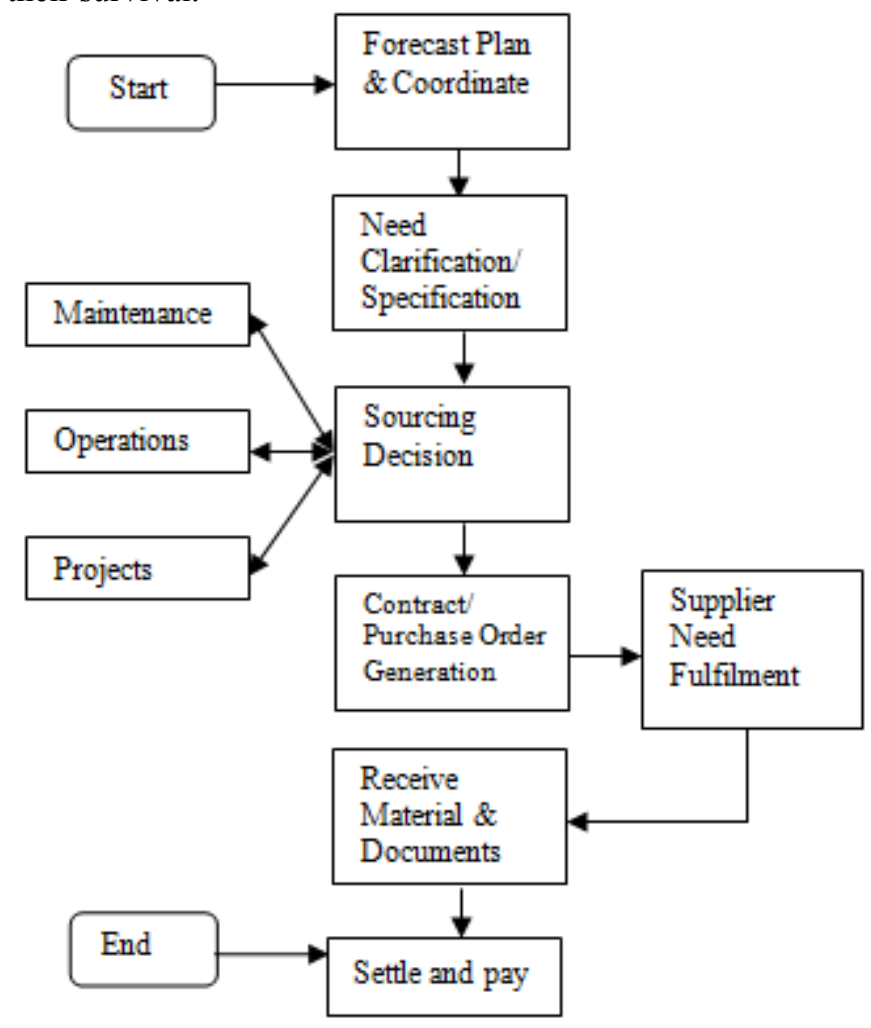

Fig. 1 An overview of procurement process [5]

SMEs are the foundation to a nation's economy, much like bricks are to a modern house. It is also the seeding ground for potential conglomerates of the future. At last count (2005), there are a total of 552,849 business establishments in the three key economic sectors in Malaysia. Out of these, 548,267 or over $99 \%$ are SMEs in manufacturing, services and agricultural sectors. Even though SMEs are defined according to the number of full time employees or annual turnover as shown in Table I and Table II below, due to their staggering number, they still employ over $56 \%$ of Malaysian workforces. Their contribution to the total GDP has been growing steadily over the past 10 years, reaching a significant $31.2 \%$ contribution by the year 2009 [6].

However, the percentage contribution of GDP by SME to the ratio of percentage of SME employments is relatively low when compared to other countries. For example, SMEs in United Kingdom employs about 48\% of UK's total workforce (SMEs are businesses employing less than 250 full time personnel according to UK's definition) but contributes to $49 \%$ of their total GDP output, at a close to $1 \%$-to- $1 \%$ ratio [7]. This shows the productivity of SMEs in Malaysia clearly can be improved substantially.

TABLE I.

SMES AS DEFINED By NuMBER OF FULL TIME EMPLOYEES [6]

\begin{tabular}{|l|l|l|}
\hline Size & $\begin{array}{l}\text { Manufacturing (including } \\
\text { agro-based) \& } \\
\text { manufacturing-related } \\
\text { services }\end{array}$ & $\begin{array}{l}\text { Primary Agriculture } \\
\text { and Services Sector } \\
\text { (including ICT) }\end{array}$ \\
\hline Micro & $>5$ employees & $>5$ employees \\
\hline Small & $5 \sim 49$ employees & $5 \sim 19$ employees \\
\hline Medium & $50-149$ employees & $20 \sim 49$ employees \\
\hline
\end{tabular}

TABLE II.

SMES AS DEFINED By ANNUAL TURNOVER [6]

\begin{tabular}{|l|l|l|}
\hline Size & $\begin{array}{l}\text { Manufacturing (including } \\
\text { agro-based) \& } \\
\text { manufacturing-related } \\
\text { services }\end{array}$ & $\begin{array}{l}\text { Primary Agriculture } \\
\text { and Services Sector } \\
\text { (including ICT) }\end{array}$ \\
\hline Micro & $>$ RM 250,000 & $>$ RM 200,000 \\
\hline Small & RM 250,000 RM 9,999,999 & $>$ RM 200,000 \\
\hline Medium & $\begin{array}{l}\text { RM 10,000,000 RM } \\
24,999,999\end{array}$ & $\begin{array}{l}\text { RM 1,000,000 } ~ \\
4,999,999\end{array}$ \\
\hline
\end{tabular}

The use of e-procurement could be the key to improving productivity among SMEs. For example, $47 \%$ of the SMEs in UK have already been using the Internet for their businesses by the year 2000 [7]. Eight years later, about $74 \%$ of them expressed their willingness to use the Internet for business [8]. In Malaysia, only about 53\% SME owners confessed that they had used the Internet in their daily business activities. Even among the SME Internet users, most only used basic application such as email [9]. In New Zealand, the low productivity of SMEs contributes to the slowing of ICT adoption by the traditional SMEs [10]. This is not definitive proof that adopting e-procurement will guarantee the excellent performance of SMEs, but the hint is strong, especially when coupled with the fact that a lot of researches have been conducted to prove the usefulness of employing ICT in business processes. 


\section{BENEFITS OF IMPLEMENTING E-PROCUREMENT}

The measurement or assessment of benefit for using ICT tools in business has been deeply studied matter in order to gain understanding of the best way to maximize advantages with the use of Internet, as well as to provide substantial evidence to convince potential adopters of its benefits. Assessment models of e-procurement and other ICT tools vary widely, due to the nature of business and application used in each case. The spectrum of benefits studied includes financial benefit studies [5] to the case study analyzing impact of e-procurement on organizations from different aspects [4]. Most of the results from these studies can be generalized to the e-procurement system, however to view these from the perspective of SMEs will require some adoptions. Two main articles by Panayiotou et al [11] and Ronchi et al [12] are reviewed in this section to represent the study of benefits of e-procurement systems in recent years. Panayiotou et al has done a fairly comprehensive study of the actual benefits of e-procurement system in governmental purchases on behalf of the General Secretariat of Commerce in Greece. In their report, benefits of using eprocurement system are categorized into tangible benefits and intangible benefits.

Tangible benefits are easily quantifiable, for example costs and time savings that translate into improved effectiveness and efficiency of organization, as well as revenue increase resulting from access to new markets or new business opportunities. Intangible benefits are the other benefits such as improved customer satisfaction, better integration of business processes, and better communication with other businesses that improve business relationships and so on, which are not so easily quantifiable. Meanwhile Ronchi et al [12]) also divided benefits of using eprocurement system into two categories, financial performance and organizational performance, the former of which are measured in definitive, financial terms while the latter is qualitative in nature (intangible) thus similar to the tangible or intangible split proposed by Panayiotou et al.

\section{A. Tangible Benefits}

Tangible benefits are quantifiable positive impact resulting from using e-procurement system, prominently in costs and time.

\section{1) Cost Savings}

Panayiotou et al [11] measured the reduction of supply costs and reduction of cost per tender in their study, reporting a $1 \%$ savings and $20 \%$ savings respectively, although the latter should be considered an opportunistic improvement as the savings was from relocation of human capitals. Savings from cost of sales, administrative cost and warehousing cost are also suggested, even though no actual values on these are given.

Ronchi et al [12], however, has identified and measured four types of cost savings from using e-procurement system in their attempt to answer the question "What is the value of an IT e-procurement system?". These are order cost, administrative cost, lead-time order cost and opportunity cost of capital. Using their assessment model they successfully predicted the cost savings of 6 different companies in 5 different industries. The data shows small reduction in administrative cost $(7.6 \%)$, and order cost (11.2\%) and enormous savings on lead-time order cost and opportunity cost of capital (88.9\% and $72.0 \%$ respectively).

\section{2) Time Savings}

While Ronchi et al [12] are able to convert lead-time into financial results, Panayiotou et al [11] reported these in raw numbers in the tender process they studied. These are 39.7\% (2.7 months) saved in open tenders and 34.7\% (4.1 months) saved in restricted tenders that were commissioned by the Greece General Secretariat of Commerce.

\section{B. Intangible Benefits}

Although cost and time savings are often cited as benefits of using an ICT system in business, fundamentally the main advantages of an ICT system are qualitative or intangible, thus they are difficult to measure in definitive terms, or even described accurately. For example, while Panayiotou et al [11] looks at intangible benefits in terms of procurement process improvement and organizational benefits (as shown in Table III), some of the benefits listed as procurement process improvement by were generalized as organizational performance improvement by Ronchi et al [12] (as shown in Table IV).

\section{SME PERPECTIVE}

Most of these benefits are applicable to businesses in SMEs, but will require few augmentations due to the nature of SMEs having smaller resource pool in terms of both financial and human capital. The perceived benefits of ICT in SMEs covered in survey conducted in Malaysia by Narayanasamy et al [13] and Tan et al [14], survey in southcoast of United States (US) by Gunasekaran et al [15] and survey in Hong Kong, China by Gunasekaran \& Ngai [16] provides some insight into the SME perspective on benefits of e-procurement systems.

\section{A. Cost- and Time- savings}

Surprisingly neither of these are ranked at the top in both Malaysia and US southcoast. This could be due to the startup cost and training or learning time that comes with the initial stages of ICT tools adoption cancelling out the actual benefits or savings gained from the ICT tools usage. The low volume of businesses SMEs normally trades at is also a main reason they perceive cost- and time-savings as minor benefits when compared to others.

TABLE III

INTANGIBLE BENEFITS OF E-PROCUREMENT SYSTEM [11]

\begin{tabular}{|l|cl|}
\hline Process improvement & Organizational benefits \\
\hline - Simpler ordering & $\bullet$ & Potential \\
- Reduced paperwork & & decentralisation of \\
- Decreased redundancy and & & procurement \\
- Less bureaucracy & More free time for \\
- Standardisation of processes and & & purchasing specialists to \\
investigate and negotiate \\
- Online reporting & & strategically important \\
- Clearer and more transparent & & issues \\
- processes & - & Wider range of suppliers \\
- Ensured compliance with & - & Improved \\
- procurement laws and regulations & & communication and \\
- Minimisation of errors & & partnerships with \\
- Easier access to information & & suppliers \\
\hline
\end{tabular}


TABLE IV

ORGANIZATIONAL BENEFITS OF E-PROCUREMENT SYSTEM [12]

\begin{tabular}{|l|l|}
\hline Benefit & Description \\
\hline Control & $\begin{array}{l}\text { Real time reporting system that enables } \\
\text { management to have fast and reliable way to } \\
\text { compare the spending with budget, allowing quick } \\
\text { reaction to any problems occuring. }\end{array}$ \\
\hline Transparency & $\begin{array}{l}\text { Tranparency of contract details such as the } \\
\text { contractual conditions, time and terms of orders } \\
\text { and etc, making these visible to relevant parties } \\
\text { both internally and externally. }\end{array}$ \\
\hline Maverick & $\begin{array}{l}\text { Refers to when a user or buyer purchases goods or } \\
\text { services out of the negotiated contracts specified by } \\
\text { his or her department. This will increase the total } \\
\text { cost of ownership of the item purchased and } \\
\text { contributes to internal inefficiency. }\end{array}$ \\
\hline Decentralization & $\begin{array}{l}\text { Decentralization of power on decision for } \\
\text { purchasing to more users within the organization, } \\
\text { thus reducing clerical work for the purchasing } \\
\text { department and improves effectiveness. }\end{array}$ \\
\hline $\begin{array}{l}\text { Supply base } \\
\text { rationalization }\end{array}$ & $\begin{array}{l}\text { Reduction and restructure of supplier base allows } \\
\text { purchasing department to maintain a database of } \\
\text { quality and price of suppliers to consolidate } \\
\text { spending. }\end{array}$ \\
\hline
\end{tabular}

\section{B. Process and Organization Improvements}

All the three studies pay little attention to benefits on process and organizational improvements, however benefits such as "better utilization of staff" [15] and "released from normal working hours" [13] are ranked second and third in respective surveys. Organizational and process restructure and improvements are perhaps more important than the researchers realized and more research should be done in these areas to improve academic knowledge on these matters.

\section{Market and Relationship}

Traditionally, SMEs are very localized, and many forged a closer relationship with their regular customers and suppliers. As such the main strength of using ICT tools from the perspective of SMEs appears to be the improvement of relationships and market position. "Improved relationship with partners and suppliers" and "increased customer service levels" are tied as number one perceived benefits of implementing e-procurement system in the US southcoast SMEs. Mean while using Internet to achieve better market position through new business opportunities, better access to market information and knowledge, and advertising/brandbuilding seems to be the top goals for Malaysian SMEs.

\section{Barriers in implementing e-procurement}

However, all these evidences of benefits raise the question: "If it's so good, then why is the e-procurement system adoption rate so low among SMEs?" In Malaysia, there are efforts from the government to popularize Internet usage among SMEs. The Malaysian Industrial Development Finance offers loan to SMEs of up to $90 \%$ for purchasing ICT applications at only $4 \%$ interest rates payable over 5 years [17]. In addition, Telekom Malaysia, one of the major Internet service providers and sole proprietor of landlines in Malaysia, established a separate entity called TM SME to help promote ICT use among SMEs. IT solutions such as cheaper Internet packages and e-marketing applications, online support platform and resources are among the services offered [18]. Multimedia Development Corporation Sdn. Bhd., in conjunction with Multimedia
Super Corridor (MSC) Malaysia also launched a Malaysia Great ICT Sale "as part of MSC Malaysia's effort to boost adoption of ICT products and services locally" [19]. However as previously stated, the adoption rate of ICT among Malaysian SMEs in their businesses is still low at around 53\% [20]. Even when they do adopt ICT, the level of sophistication of the ICT tools used by SMEs are expected to be low [21], as the high sales volume is one of the major factor large companies are able to employ more sophisticated websites.

There is somehow few researches done that investigates the use and the potential barriers on the use of eprocurement specifically in the SME. The pool of researches on organizational level in barriers of eprocurement adoption or ICT tools adoption in SMEs, however, is much larger. Therefore in reviewing these researches potential barriers for e-procurement implementation among SMEs can be observed. Based on previous researches, the factors contributing to barriers will depend on many factors, including external factors such as technology, infrastructure and legislation, environment; and internal factors such as resource constraints and organizational and management characteristics.

\section{A. External Barriers}

External factors from the industry, market, government and technology change are often out of control of an SME owner. However with collective efforts some external barriers can be minimized, even completely mitigated.

\section{1) Technology}

Arguably the issues stemming from the use of eprocurement is not an external barrier, but only on the assumption that the users are involved in the development of the system itself. Lack of support from system developers and vendors poses a barrier to e-procurement system uptake of SMEs. As noted by Stockdale \& Standing [22], understanding or commitment to a specialist software and startup fee that are beyond the capability of SMEs may be required by the vendors. Focus of support for the systems are also usually on the larger companies. Others such as Chan \& Lee [23] and Tan et al [14] proposed that the perceived power or usefulness of the system itself is a determinant for adoptioning an ICT system. Security of the system is also a major concern for potential adopters [24].

\section{2) Infrastructure and Legislation}

Inadequacies in government policies and legislation can affect the uptake of an ICT system [25], [24]. For example, the standard procedure for governmental tendering process mandates the buying of printed tender documents in physical offices by interested parties in person. This effectively prohibits the use of e-tendering system and presents a huge setback for the government's attempt to establish an electronic government system. Wide-spread use of e-procurement system also depends on the availability of supporting infrastructures, such as sufficient broadband coverage.

Another issue to highlight is the lack of standards in the development of e-procurement system. Different developers may use different standard for their product. As a result users of one system cannot communicate electronically with users of other systems, creating a diverse but fragmented e- 
procurement environment. Value of a network increases exponentially with the number of users connected [26], thus a fragmented e-procurement environment will decrease the system's overall value. This will prove detrimental to both vendors and users in the long term.

\section{3) Environment}

The saturated market condition and increased competition in the industry will create sufficient pressure for SMEs to adopt e-procurement [14], [27]. This is especially true in the firms that are exploring the international market [28, 27]. However, there are conditions where businesses choose not to use e-procurement system to maintain trust and close relationship with their suppliers or customers [28, 29]. Sometimes, the reverse can happen: suppliers or customers do not trust their counterparts enough to complete a deal [23, 30]. This phenomena, perhaps, contributes to the 'wait-andsee' behavior so commonly found among SMEs. Suppliers or customers displaying a token from a third party to demonstrate their genuity and integrity should be made a common practice within any e-procurement environment.

\section{B. Internal Barriers}

Internal barriers are issues within a SME firm can be eradicated or minimized with the SME owner's own effort. Resource contraints such as financial and human capital along with organizational and management characteristics such as organizational culture, decision maker's perception of risk and benefits of e-procurement system [8], firm size, business type, organization structure and others. Some of these barriers are inter-related and hard to be clearly definited, for example the lack of financial capital due to small firm size and volume of business can affect the owner to become risk-adverse when asked to invest in a eprocurement system. However with collective efforts some external barriers can be minimized, even completely mitigated.

\section{1) Resource Constraints}

One of the characteristics defining SMEs is that their financial capital is small, and number of employees are few. As such the allocation of these resources require careful consideration from the decision maker, often the sole owner of the business himself. As such, paying the cost of taking up e-procurement presents a huge risk to SME owner. Often, the owner or employees also has no technical expertise or knowledge of e-procurement systems [25, 24, 22]. This lack of human resource with technical knowledge combined with lack of financial capacity to risk such as absorb eprocurement system failure are issues most strongly explains the 'wait-and-see' attitude of SME owners, which are less common among large companies. However with collective efforts some external barriers can be minimized, even completely mitigated.

\section{2) Organizational and Management Characteristics}

The characteristics of firm is found to be a factor affecting e-procurement adoption in businesses. Business type, larger firm size in terms of financial capacity and number of employees per physical establishment, and involvement with international trade or international groups are found to be favorable to e-procurement adoption. Meanwhile managerial characteristics such as company policy (use of Quality Assurance System ), organization structure, supply chain integration, and, especially in the case of SMEs, the decision maker's attitude towards ICT are important determinants of e-procurement adoption in businesses [28, 30,25, 27].

\section{IMPROVING ADOPTION OF E-PROCUREMENT IN SMALL AND MEDIUM ENTERPRISES}

The survey has nevertheless highlighted the numerous benefits for e-procurement adoption in SMEs, especially in time and cost saving. However, significant efforts are required for Malaysian SMEs to exploit such benefits as they are hindered by external and internal barriers. First and foremost is the need to build e-procurement on common models and approaches. Currently there are a few purchasing platforms in Malaysia for instance, Ariba, Oracle/PeopleSoft, SAP, Epicor and Perfect Commerce. Concept like the Pan-European Public Procurement Online (PEPPOL) by European Union which allows the European companies to participate equally in EU public sector competitive bidding [31] needs to be initiated in Malaysia. Infrastructure solutions to improve and enhance interoperability between the firms e-procurement system should be encouraged and with local government's system as well since government is one of the largest consumers. This would help eliminate unnecessary technical barriers among e-procurement participants. Besides, local government can also use legislation to incentive contracting parties to adopt e-procurement by reducing publication deadlines. For instance, decrease the time for tender notification and submission will indirectly push firms to migrate to e-procurement as it can provide unrestricted and full direct access to relevant documents.

Furthermore, policy and best-practice regarding the use of electronic medium should be incorporated into the firms' environment in addition to techniques and tools relevant to e-procurement. This will allow employees to learn from existing experience of others and make full use of electronic tools to improve procurement activities to eliminate the "wait and see" attitude and therefore speed up the adoption of e-procurement system. Besides this, ample support for training users and continued efforts by system developers and vendors to promote and develop their e-procurement systems are needed to ensure a successful e-procurement system implementation.

Nonetheless, the lack of financial resources is one of the major barriers to e-procurement. Co-financed research and cooperation in development of relevant tools to overcome administrative and technical barriers should be undertaken among firms. On the other hand, local government who is the coordinator of the country could coordinate such strategy by providing grants and financial incentives to those cooperation firms. Undoubtedly, vast time and efforts are needed to realize these steps to improve e-procurement adoption but it is essential for the creation of sustainable and innovative SMEs.

\section{CONCLUSIONS}

SMEs, making up to $99 \%$ of all registered businesses, are the backbone of a nation's economy. It is imperative that their productivity to be as high as possible. ICT tools are 
important invention to help SMEs increase their effectiveness and efficiency by improving business communications, business process, reduce cost and cycle time, explore new market and business opportunities, increase transparency in contracts and overall competitiveness. E-procurement system is suitable for these purposes due to its advantages of use in business settings.

However, e-procurement is not widely adopted among SMEs. Existing external factors that presents a barrier to adoption of e-procurement among SMEs are discovered, as well as internal factors that resides within firms. Three groups of external barriers identified are technology, infrastructure and legislation, and environment. Meanwhile resource constraints and organizational characteristics form the two groups of internal barriers impeding adoption of eprocurement. Overcoming these barriers would require efforts from all stakeholders, including the government, system developers and vendors, SME owners and employees as well as regulatory bodies in respective businesses.

While this survey identifies a number of benefits and barriers to the implementation of e-procurement system in SMEs, it does not provide a holistic view on adoption of ICTs in SMEs. The procurement process and e-procurement barriers framework is only a simplified version of the barriers and the real purchasing process in a firm. The study can be expanded to include the determinants and factors of e-procurement implementation. Also, it is interesting to assess the impact and effectiveness of e-procurement usage in different industries or other countries. In addition, further study can be conducted to evaluate the potential risk and impact for firm to migrate to e-procurement.

\section{ACKNOWLEDGMENT}

We would like to thank Universiti Sains Malaysia for supporting this study.

\section{REFERENCES}

[1] R. T Griffiths, (2002, October 11). History of the Internet, Internet for Historians(and just about everyone else). [online]. Available: http://www.let.leidenuniv.nl/history/ivh/frame_theorie.html

[2] Miniwatts Marketing Group. (2011, February 14). United States of America - Internet Usage and Broadband Usage Report. [Online] Available: http://www.internetworldstats.com/am/us.htm

[3] S. D. White, (2010, August 20). U.S. E-Commerce Growth 20002009. [Online]. Available: http://dstevenwhite.com/2010/08/20/u-se-commerce-growth-2000-2009/

[4] S. Croom, A. Brandon-Jones, Impact of E-procurement: Experiences from Implementation in the UK Public Sector. Journal of Purchasing \& Supply Management , 13, pp 294-30, 2007.

[5] P. Trkman., K. McCormack, Estimating the Benefits and Risks of Implementing E-Procurement. IEEE Transactions on Engineering Management, 57 (2), pp 338-349, 2010.

[6] National SME Development Council. (2010). SME Annual Report 2009/10.[Online].

[7] J. Rowe, (2008). SME Value and Contribution to the UK Economy. [Online]. Availablle: http://www.buzzle.com/articles/ sme-valueand-contribution-to-the-uk-economy.html

[8] I. Fillis, U. Johannson, B. Wagner, Factors impacting on e-business adoption and development in the smaller firm. International Journal of Entrepreneurial Behaviour \& Research , 10 (3), pp 178-191, 2004
[9] H. Hollenstein, Determinants of the adoption of Information and Communication Technologies (ICT): An empirical analysis based on firm-level data for the Swiss business sector. Structural Change and Economic Dynamics, 15, pp 315-342, 2004.

[10] T. Beal,.Government Promotion and Facilitation of ICT use by SMEs: APEC and New Zealand Perspectives. Asia Small Business Review, pp 25, 2001.

[11] N. A. Panayiotou, S. P. Gayialis, I. P. Tatsiopoulos, An EProcurement System for Governmental Purchasing. International Journal of Production Economics, 90, pp 79-102, 2004.

[12] S. Ronchi, A. Brun, R. Golini,, X. Fan, What is the Value of an IT e-Procurement System? Journal ofPurchasing\&SupplyManagement , 16, pp 131-140, 2010.

[13] K. Narayanasamy, A.S. Santhapparaj, U. C. Eze, An Empirical Study of Website Adoption among Small and Medium Enterprises (SMEs) in Malaysia. Comm. of the IBIMA , 2, pp 50-62, 2008.

[14] K. S. Tan,, S. C. Chong., B. Lin, U. C. Eze, Internet-based ICT Adoption: Evidence from Malaysian SMEs. Industrial Management \& Data Systems , 109 (2), pp 224-244, 2009.

[15] A. Gunasekaran, R. E. McGaughey, E.W. Ngai, B. K. Rai,. EProcurement Adoption in the Southcoast SMEs. Int. J. Production Economics , 122, pp 161-175, 2009.

[16] A. Gunasekaran, E. W. Ngai, Adoption of E-procurement in Hong Kong: An Empirical Research. International Journal of Production Economics , 113, pp 159-175, 2008.

[17] Malaysian Industrial Development Finance Berhad. (2001). Malaysian Industrial Development Finance Berhad. Retrieved February 11, 2011, from Soft Loan Scheme for Small \& Medium Enterprise (SLSME).

[18] Telekom Malaysia Berhad. (2009, August 17). Telekom Malaysia. Retrieved February 12, 2011, from TM Introduces TM SME One Plan Offering Big Value, Low Cost for SMEs. [Online]. Available: http://www.tm.com.my/about-tm/media-centre/pressrelease/Pages/tm_introduces_tm_sme_one_plan_offering_big_value low cost for_smes.aspx

[19] MSC Malaysia. (2009). MSC Malaysia Great ICT Sale. [Onl;ine] Available: http://www.mscmalaysia.my/topic/Great+ICT+Sale

[20] J. Hasim, Information Communication Technology (ICT) Adoption Among SME Owners in Malaysia. International Journal of Business and Information , 2 (2), pp 221-240, 2007.

[21] M. T. Tiago, J. P. Couto,. F. B. Tiago, J. A. Vieira, Internet Marketing Adoption: Factors Affecting Website Sophistication. Int. J. Electronic Customer R. Management, 1 (3), pp 287-306, 2007.

[22] R. Stockdale,C. Standing, Benefits and Barriers of Electronic Marketplace Participation: An SME Perspective. The Journal of Enterprise Information Management, 17 (4), pp 301-311, 2004.

[23] J. K.Chan, M. K Lee, SME E-Procurement Adoption in Hong Kong - The Roles of Power, Trust and Value. 36th Hawaii International Conference on System Sciences. Hawaii: IEEE Explore, 2003.

[24] H.Ongori, S. O. Migiro, Information and Communication Technologies Adoption in SMEs: Literature Review. Journal of Chinese Entrepreneurship , 2 (1), pp 93-104, 2010.

[25] K. Karjalainen, K. Kemppainen, The Involvement of SME in Public Procurement: Impact of Resource Perceptions Electronic Systems and Enterprise Size. Journal of Purchasing \& Supply Management , 14, pp 230-240, 2008.

[26] Wikipedia. (2001, January 17). Metcalfe's law. [Online]. Available: http://en.wikipedia.org/wiki/Metcalfe's law

[27] J. Zheng, N. Caldwell, C. Harland, P. Powell, M. Woerndl, S. Xu, Small Firms and e-Business: Cautiousness Contigency and CostBenefit. J of Purchasing \& Supply Management, 10, pp 27-39, 2004.

[28] A. Bayo-Moriones, F. Lera-Lopez, A Firm-level Analysis of Determinants of ICT Adoption in Spain, Tech. 27, pp 352-366, 2007.

[29] R. L. Hsiao, T. S. Teo, Delivering on the Promise of E-Procurement. MIS Quarterly Executive, 4 (3), pp 343-360, 2005.

[30] M. Johnson, (2010). Barriers to Innovation Adoption: A Study of eMarkets. Industrial M \& Data Systems , 110 (2), pp 157-174.

[31] Basware (2011). EU Public Sector e-Procurement Initiative Delivers First Phase of Standard e-Procurement Platform Project. [Online]. Available: http://www.basware.com/News and Events/ News/Pages/EUPublicSectoreProcurementInitiativeDeliversFirstPha se ofStandarde-ProcurementPlatformProject.aspx 